\title{
The Teacher Assistant Programme Across The UAE: Empower To Include
}

\author{
Eman Gaad, British University in Dubai, UAE
}

\begin{abstract}
This paper presents the findings of a government-funded research project that was aimed at providing well-trained teacher assistants to enable inclusion of learners with intellectual disabilities in 21 Emirati government schools across the United Arab Emirates. The project is a first in the country and attracted media attention because of its dual benefit in not only supporting the national trend of the inclusion of learners with disabilities in mainstream schools, but also enabling empowerment of young Emirati women who did not make it to higher education for some reason or another but are keen to join the work force.

The main research question was, "what is the impact of the programme on the lives of those Emirati women who became teacher assistants and on the education process in the school where they were trained?" Mixed methods were applied to achieve the aims of the project. Provisional results showed that having a well-trained teacher assistant in class, alongside the class teacher in Emirati mainstream schools, supports and empowers young learners with intellectual disabilities and contributes to an effective and long-lasting inclusive education. In relation to the Emirati trainees, the programme was effective and it supported such young women to secure a place in the work force as well as equipped them with new skills that they found useful for their own selfdevelopment and their respective communities across the UAE. The project was funded by the Emirates Foundation for the UAE Down Syndrome Association in collaboration with the British University in Dubai and the Ministry of Education in the UAE.
\end{abstract}

Keywords: Teachers Assistants; Inclusive Education; Female Empowerment; Down Syndrome; UAE

\section{INTRODUCTION}

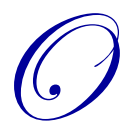

il is considered the main source of income for the United Arab Emirates (UAE). The discovery of oil was very effective in leading to major development in all aspects of life in the UAE such as economy, health, social affairs and educational fields (Gaad, 2010). Although the UAE is a small country, it has achieved great development in various fields of life which has made the UAE a pivotal country in the region (Abdalla, 2011). At present, the UAE's education system comprises two separate sectors - the public sector, in which this study was conducted, and the private sector. The public sector is funded by the government and only educates Emirati children. This rule is the result of the Ministry of Education's decision to enroll only nationals in national schools (Gaad, 2006). The private sector caters for the ever-increasing number of expatriate children. Emirati children have the choice of which sector they are educated in; however, expatriates do not and they have no alternative but to attend private schools. Schools in both sectors are governed by the Ministry of Education, yet it would appear that schools in the private sector have greater autonomy than their public sector counterparts (Spencer, 2010). It is worth mentioning that all mainstream public education is conducted in single gender classes (Gaad, 2001) and all primary government education is governed and delivered by female staff, including teachers, management and administrative staff.

The educational system in the UAE is built on Islamic human rights which encompass the right to equality, the right to social welfare and basic necessities of life, the right to dignity, not to be abused or ridiculed, and the right to education (Bradshaw et al., 2004). The last decade witnessed a leap in the area of adopting the rights-based approach for those who may require different provisions in education, and inclusion of learners with disabilities in 
regular classroom settings was on the top of the agenda of reformers and innovators. This was natural as the UAE proceeded with the ratification of the UN Convention on the Rights of Persons with Disabilities in March 2010, following the Federal Law No. 29/2006 and its amendment through Law No. 14/2009 (Ministry of Social Affairs, 2006).

Several federal and local initiatives have been proposed to support the inclusion trend, and most noticeable was the 'Schools For All initiative' by the Ministry of Education in 2010 where selected schools across the UAE were allocated pilot-inclusive education. It was noticed, however, that the idea of having a teacher assistant or learning support aide was not incorporated in each inclusive class; instead, special needs coordinators who were trained in each school opted for a special educator who would advise and support all teachers in the school rather than having an allocated teacher assistant in each inclusive classroom. Literature in the field shows that there is a professional need for assistant teachers as trained personnel in order for the inclusion process to take place effectively. Therefore, investing in well-trained teacher assistants to support teachers and schools is inevitable to enable inclusion special needs learners in mainstream schools. Given the above and the fact that learners with intellectual disabilities are more vulnerable to be last on the list for inclusion into mainstream schools (Gaad, 2010), it was important to support the inclusion process in the country through training assistant teachers to serve in inclusive classrooms, particularly, and, more urgently, to support the inclusion of learners with intellectual disabilities in a nation with a higher-than-average rate of live births of individuals with Down Syndrome. The latter is deemed as the leading cause for intellectual disabilities.

In a mainstream school, special provision can be made for a child by providing extra adult support. "Mainstream schools have long been expected to make provision for those pupils who have some special needs...through the provision of extra support" (Everard et al., 2004). The amount of extra support allocated to a child varies according to factors such as perceived need and the school's budget. The way in which this support is delivered is also subject to variation. Support can take the form of either 'pull-in' support, whereby an extra member of staff works with the child in their mainstream classroom, or 'pull-out' support which can also be referred to as withdrawal. During pull-out or withdrawal support, the child leaves the mainstream classroom in order to attend an alternative setting where the support is provided. This pull-out support is usually delivered by a special educator who is qualified to help meet the child's needs, but the child could also be supported by a Learning Support Assistant. On occasions, schools will employ such assistants because they are a cheaper financial alternative to a special educator, yet still provide the required "support" for the child (Spencer, 2010). Since recent research in the UAE indicates that teachers are more reluctant to include learners with disabilities into mainstream schools because of fear of them not coping with the heavy inflexible curriculum (Gaad, 2010), the idea of training female teacher assistants to be placed in inclusive schools across the country was developed particularly to support those learners who may be at risk of not being included or to be the last on the list due to their intellectual disabilities and complex needs.

\section{Teacher Assistant Project: A Brief Background}

The overall goal of this project was to train 21 Emirati females, who have at least a secondary school certificate, to become teacher assistants in 21 Emirati government schools across the seven UAE Emirates (three per each Emirate). Training took five months, including theoretical and practical courses offered by an accredited university. Following advertising and selection process, a contract was signed to commit such trainees to the inclusion programme in their Emirate. The project kicked off in February 2012 and closed in March 2013. 
The schools in each Emirate were selected as nominated by the Local Educational authorities. A course to train assistant teachers was designed and advertisements were made through newspapers to recruit female Emiratis (as all primary government schools are feminized). A selection process took place according to the following simple criteria:

- $\quad$ UAE Nationals from the seven Emirates equally

- $\quad$ Willing to help and support learners with disabilities, especially intellectual disabilities

- Willing to participate in a five-month training course (some parts are online and some are face-to-face)

- Willing to be interviewed by schools and, if accepted, work for one academic year in the local selected government school

- $\quad$ Believes in all the global values on inclusion of people with disabilities in education and life

Following the course, it was expected that female non-working Emiratis who are looking for sustainable jobs would acquire knowledge and skills that empower them as productive members in the UAE society. A Memorandum of Understanding between the UAE Down Syndrome Association and the British University in Dubai was signed to secure commitment to the delivery of the course. The Course was designed and delivered by a worldrenowned scholar in the field of special and inclusive studies with a specialism in Down Syndrome.

At the end of the training course targeted participants were expected to:

- Gain knowledge on the types of disabilities with focus on intellectual disabilities (the UAE has one of highest rates of Down syndrome in the world)

- $\quad$ Learn skills to support learners with intellectual disabilities in government inclusive classrooms

- Work with class teachers to draw up an individualised educational and social plan to include learners with disabilities

- $\quad$ Successfully pass and complete the course

- $\quad$ Apply what they have learned in the field of work

- Work as teacher assistant trainees in selected schools from September 2012 - March 2013

The project was proposed for funding by the leading Non-Government Organization that cares for people with Down Syndrome - the UAE Down Syndrome Association (UAEDSA). It was proposed in collaboration with one of the leading research-based universities in the area of special and inclusive education - the British University in Dubai - and the funds were granted by the Emirates Foundation, an Abu Dhabi federal body that supports and funds research in the area of social development.

The UAEDSA itself began in 2004 as a small group of families having a member with Down Syndrome for one year, under the umbrella of Dubai Ladies Club. H. H. Sheikh Manal Bint Mohd, Dubai Ladies' Club President, recognised the hard work and community support provided by the Down Syndrome Group and she honoured the group with her patronage, which gave them immense support. The UAE Down Syndrome was officially turned into an association in September 2006 by the Ministry of Social Affairs (MOSA). The Association now has over 500 family members, comprising more than 17 nationalities with children from just a few months old to $40+$ years of age.

\section{METHODOLOGY, ETHICS \& LIMITATION}

Interviews were the main qualititative tool used to collect data. By interviewing the participants (the trainee teacher assistants) and the teachers in schools, the researcher could ensure that the participants understood the questions and had the opportunity to confirm their answers. As Bell (2005, p. 157) asserts, "a skillful interviewer can follow up ideas, probe responses, and investigate...feelings, which the questionnaire can never do."

The researcher conducted this qualitative study using purposeful sampling, so seven assistant teachers trainees, three teachers who supervised some of the trainees, and a head of one of the schools were selected for interviews. The participants were given pseudonyms to maintain anonymity. Document analysis was used as 
research-based evidence in the inclusion process in terms of academic and social achievement of the included learners. Course validated assignments that included fieldwork related to working with a teacher in a local school were also analysed. Interim reports by student team leaders also gave additional evidence, which is in addition to notes from the exit (end of pilot project) evaluation that included observations and interviews with participants and their supervisors. This study was conducted with rigor and intent to maximize useful outcomes for the field of inclusive education.

Project implementation was monitored across one academic year and recommendations were made for future practice. Table 1 details the risks and limitations the researcher examined before conducting the research:

Table 1: Project Risk Management Map

\begin{tabular}{|l|l|}
\hline \multicolumn{1}{|c|}{ Risks } & \multicolumn{1}{c|}{ Mitigation } \\
\hline $\begin{array}{l}\text { Requirement of the course is not clear and not matching the } \\
\text { needs of the field }\end{array}$ & $\begin{array}{l}\text { Getting a well-known university to design, validate, and } \\
\text { implement the course }\end{array}$ \\
\hline Failure to recruit participants & $\begin{array}{l}\text { Collaborating with local Tanmia and NDP to get CVs of } \\
\text { diploma and secondary degree Emirati females } \\
\text { Advertise in national papers to recruit }\end{array}$ \\
\hline Geographical challenges to deliver the course & $\begin{array}{l}\text { Deliver the course in various modes and have group work in } \\
\text { designated Emirates rather than everyone travelling to Dubai } \\
\text { or Abu Dhabi }\end{array}$ \\
\hline Monitoring challenges & $\begin{array}{l}\text { One of the three students will be the team leader and } \\
\text { responsible for reporting } \\
\text { A mentor from the school will be identified for any day-to-day } \\
\text { issues } \\
\text { Telephone and online help line will be set up }\end{array}$ \\
\hline Materials for the course & $\begin{array}{l}\text { Will be covered by the university + an access to university } \\
\text { library and catalogue }\end{array}$ \\
\hline $\begin{array}{l}\text { Schools are not interested in implementing the inclusive } \\
\text { experience }\end{array}$ & $\begin{array}{l}\text { Project will be using 'Schools for all' that are already } \\
\text { implementing inclusive education so there is no running out of } \\
\text { inclusive schools across all Emirate }\end{array}$ \\
\hline
\end{tabular}

Table 2 consists of the phases of the project with dates:

Table 2: Phases Of The Research Project

\begin{tabular}{|l|c|c|}
\hline \multicolumn{1}{|c|}{ Phase } & From & Duration \\
\cline { 2 - 3 } & $01-11-2011$ & $30-11-2011$ \\
\hline Signing MoUs between BUiD + UAEDSA and MOE and UAEDSA & $1 / 11 /-2011$ & $15-12-2011$ \\
\hline Designing the course & $15 / 12 / 2011$ & $15-01-2012$ \\
\hline $\begin{array}{l}\text { Advertising for recruitment of candidates + selection process+ signature } \\
\text { of agreement with candidates }\end{array}$ & $15-01-2012$ & $30-01-2012$ \\
\hline Selection of schools following nomination of MoE & $01-02-2012$ & $30-06-2012$ \\
\hline Delivering the theory course elements & $01-07-2012$ & $31-08-2012$ \\
\hline Summer readings and theoretical assignments & $15-09-2012$ & $31-12-2012$ \\
\hline Delivering the practicum course elements & $01-01-2013$ & $01-02-2013$ \\
\hline Working on assignments + preparing for Exam & $02-02-2013$ & $28-02-2013$ \\
\hline Examination and final results announced & $01-03-2013$ & $30-04-2013$ \\
\hline Writing up the final report of the project & & \\
\hline
\end{tabular}

\section{FINDINGS}

A total of 24 trainees completed the entire course with only one who stepped off for one month due to mitigating issues. The following are some of the quotes from the trainees when asked about the impact of the programme on their lives:

Amal, who was 28 at the time of the interview, stated, "I have never worked in my life and this gave my an aim in life. To be able to help those kids is more than satisfying. I love being around them." 
Nora, aged 42 and a mother of two, said, "I never thought I could be working one day. I finished high school, got married, had children and never had a chance to be in the workforce. I used to be jealous of those working women; now I am going to be one of them".

Ahlam is 38 and unmarried. She claims that the programme changed her life and gave her "a purpose to have every day". She wanted to be "a productive member of her community after years of 'staring at the ceiling"."

Others expressed their initial anxiety at first as they had not been in formal education for years, but joining the programme was worth the effort.

The project also enjoyed extensive media coverage and the following are some of the quotes:

Zahra, 35, said she will be working at the primary school for Boys in Dubai. "I have bonded with my student Abdullah, 11", she said. "He is in grade 4. Helping him makes me very happy." (Gulf News, 1/2/2103)

Sina Al Kulaib, 40, is training at the Dubai Modern Education School with 12-year-old Alia. "This is the kind of job I have always wanted to do," she said. (Gulf News 1/2/2103)

Rihab Hashim Al Hashimi, 29, from Shurooq Kindergarten, is training to look after Shamma, six, who has Down Syndrome. She also helps with Rashid, six, who has autism. "I hope to join full-time soon," she said. (Gulf News $1 / 2 / 2103)$

A teacher who supervised the trainees expressed her gratitude to have 'helping hands' while another welcomed the 'extra support to facilitate' inclusion. At the same time, a school head teacher echoed that and was excited that the country is 'finally doing something about inclusion and they are finally investing in someone to become an assistant teacher'.

\section{CONCLUSION}

This research was conducted with the aim of determining the impact that the teacher assistant programme had on the lives of Emirati female teacher assistant trainees in terms of empowerment. It is clear that from the way the participants viewed and experienced supporting children with special needs, they found the programme to be helpful, life changing, and, indeed, empowering. With regard to inclusion, since the late 90 's, a wider view of inclusive education has begun to see its way into more countries in the region (Gaad, 2010). Recently, ministries of education in most Arab states began adopting policies and guidelines for implementing inclusive education. Gaad (2004) claims that the country in which this study was conducted - the UAE - was just "catching up." Therefore, a follow-up study is recommended to examine the impact of the programme on learners with special needs themselves in the Emirati schools, providing a clear definition of who has special educational needs in this setting. This is in addition to the impact on the inclusion process that the country is adopting at present. It is clear that Learning Support Rooms, which for many years have been used as safety nets (Spencer, 2010), are now not the only option to educate a child with special needs in a mainstream school. The government sector has attempted to bridge the gap and hopefully, with the assistance of the teacher assistants, a move in the right direction is in place. One could argue that this humble piece of research is a good starting step to see the effect of the programme on its participants considering this is something new in a relatively young country that is newly adopting inclusion of all learners in regular settings and looks at training teacher assistants to support the cause.

Throughout recent developments, education has been an underlying theme affecting the UAE's policy decisions. Children with special educational needs have not been specifically discussed within this. However, the UAE Federal law number 29, article 12 (2006) states, "The country assures equivalent educational chances for the Person with Special needs in all educational establishments." Emirati children with special educational needs are provided for by the state - "the provision of special needs facilities includes free school placements, but only for national children" (Gaad, 2001). Therefore, the teacher assistant programme is no longer a luxury or a choice; it is a necessity. To have a comprehensive programme that supports the inclusive policy is commendable, but to apply such a programme to empower female Emiratis and use them to be part of the development of their young is certainly promising and encouraging for the future. 


\section{AUTHOR INFORMATION}

Professor Eman Gaad is the Dean of the Faculty of Education and a Professor of Special and Inclusive Education at British University in Dubai. Professor Gaad led the university's special and inclusive Masters programme for many years and currently leads the Doctorate Programme. She co-founded one of the largest NGOs in the UAE UAEDSA - and is one of the governors of the regionally outstanding Dubai College as well as on the Board of Directors of several non-profit organizations in the UAE and the region. She is a UNESCO Consultant and has advised policy and decision-makers as a senior consultant for both governments of Dubai and Abu Dhabi on disability related issues. She is also a winner of HH Princess Haya Award for Special Education as best distinguished individual research in 2012 and, in the same year, was awarded the Global Leadership in Education Award from the Asian Leadership Award Board. She has established herself as a world class researcher, advocate, international social development consultant and expert, certified assessor, and professional social trainer.

\section{REFERENCES}

1. Abdalla, K. (2011). Current Status of Gifted and Talented Learners in Cycle 2 Government Schools in Abu Dhabi Emirate: an Analytical Study. Unpublished MEd dissertation, British University in Dubai, Awarded June 2012.

2. Bell, J. (2005). Doing Your Research Project $\left(4^{\text {th }}\right.$ Edn). Berkshire: Open University Press.

3. Bradshaw, K., Tennant, L., \& Lydiatt, S. (2004). Special Education in the United Arab Emirates: Anxieties, Attitudes and Aspirations. International Journal of Special Education, vol. 19(1), pp. 49-55.

4. D’Souza, C. (2013). 24 Emirati women to help as teaching assistants. Gulf News, February 1, 2014.

5. Everard, K. B., Morris, G., \& Wilson, I. (2004). Effective school management. (4th Edition). London: Paul Chapman Publishing.

6. Gaad, E. (2001). Educating children with Down Syndrome in the United Arab Emirates. British Journal of Special Education, Vol. 28(4), pp. 195-203.

7. Gaad, E. (2004). Including students with Exceptional Learning needs in regular schools in the United Arab Emirates. The International Journal of Diversity in organisations, communities and nations, Vol. 4.

8. Gaad, E. (2006). Crossing the Barriers: Culturally diverse teachers teaching in Culturally diverse mixed abilities classrooms in the United Arab Emirates. The International Journal of Diversity in organisations, communities and nations, Vol. 5, (2005/2006).

9. Gaad, E., Arif, M., and Scott, F. (2006). Systems analysis of the UAE education system. International Journal of Educational Management, Vol. 20, No. 4. (2006), pp. 291-303.

10. Gaad, E. (2010). Inclusive Education in the Middle East. UK: Routleadge.

11. Ministry of Social Affairs. (2006). UAE Federal Law No. 29 of the Year 2006 on the Rights of People with Special Needs. UAE: Ministry of Social Affairs Publication.

12. Spencer, T. (2010). An Investigation into the effectiveness of the Learning Support room in an Emirati primary school. Unpublished MEd dissertation, The British University in Dubai. 